\title{
Infections caused by herpes simplex virus, varicella-zoster virus and Epstein-Barr virus in organ transplant recipients, and their diagnosis
}

F DIAZ-MITOMA, MD, PHD, FRCPC

F Diaz-Miтoma. Infections caused by herpes simplex virus, varicella-zoster virus and Epstein-Barr virus in organ transplant recipients, and their diagnosis. Can J Infect Dis 1993;4(Suppl C):33C-40C. Immunosuppressed patients are at risk of severe herpesvirus infections. Herpes simplex (HSV), varicellazoster (VZV) and Epstein-Barr virus (EBV) infections are associated with characteristic syndromes in this population. Typically HSV and VZV infections cause mucocutaneous lesions; diagnosis is usually confirmed by tissue culture or fluorescent microscopy. The availability of effective antiviral agents, and accurate techniques for laboratory diagnosis have improved the management of HSV and VZV infections. Antibody assays to demonstrate HSV or VZV infections are of limited value in immunocompromised patients, because the presence of antibodies does not indicate a decreased risk for HSV, varicella or zoster, but indicates susceptibility for reactivated infection. EBV is associated with lymphoproliferative disorders in transplant recipients. Infection of lymphocytes by EBV is a necessary step in achieving $\mathrm{B}$ cell transformation and immortalization. The lack of immunosurveillance against EBV-transformed B cells predisposes patients to developing invasive infiltration of transformed B cells. Diagnostic methods for EBV infections include lymphocyte transformation, serology, and detection of DNA by direct hybridization or by DNA amplification. Quantitative oropharyngeal EBV shedding is a good marker for the development of lymphoproliferative disease in transplant recipients. Patients experiencing primary EBV infection are at the highest risk for lymphoproliferative disorders. Prophylactic antiviral therapy may be of benefit in preventing EBV replication and therefore in decreasing the risk for lymphoproliferation.

Key Words: Epstein-Barr virus, Herpes simplex, Transplantation, Varicella-zoster virus

\section{Les infections provoquées par l'herpès simplex, l'herpèsvirus varicellae et le virus Epstein-Barr chez les receveurs de transplantations d'organes et leur diagnostic}

RÉSUMÉ Le patient immunosupprimé court un risque d'infection grave à herpèsvirus. Les infections à herpès simplex (HSV), à herpèsvirus varicellae (VZV) et au virus Epstein-Barr (EBV) sont associées à des syndromes caractéristiques dans cette population. De façon typique, les infections à HSV et VZV provoquent des lésions mucocutanées: le diagnostic est généralement confirmé à l'aide de cultures de tissus ou de microscopies à fluorescence. La disponibilité d'agents antiviraux efficaces et de techniques précises pour 


\begin{abstract}
le diagnostic en laboratoire ont amélioré le traitement des infections à HMV et à VZV. Les techniques immunologiques en vue de démontrer la présence d'infections à HMV ou à VZV ont une valeur limitée chez les patients immunocompromis parce que la présence d'anticorps n'est pas synonyme d'un risque moindre à l'égard du HSV, de l'herpèsvirus varicellae ou de l'herpès zoster, mais indique une sensibilité à l'égard de l'infection réactivée. L'EBV est associé à des maladies lymphoprolifératives chez les receveurs de transplantations. L'infection des lymphocytes par le virus EBV est une étape nécessaire à la transformation et à l'immortalisation des cellules B. L'absence d'immunosurveillance contre les cellules transformées par EVB prédispose les patients à une infiltration invasive de cellules B transformées. Les méthodes diagnostiques pour le dépistage des infections à EBV incluent la transformation des lymphocytes, la sérologie et le dépistage de l'ADN par hybridation directe ou par amplification de l'ADN. La libération quantitative oropharyngée d'EBV est un bon indicateur du développement de la maladie lymphoproliférative chez le receveur de transplantation. Les patients qui présentent une infection à EBV primaire sont le plus à risque à l'égard des maladies lymphoprolifératives. Le traitement antiviral prophylactique peut être utile à prévenir la réplication de l'EBV et donc à diminuer le risque de lymphoprolifération.
\end{abstract}

$\mathrm{M}$ ORE THAN 80 HERPESVIRUSES HAVE BEEN ISOLATED from a wide variety of animal species (1). Only seven herpesviruses have been isolated from humans, including herpes simplex virus 1 (HSV-1) and herpes simplex virus 2 (HSV-2), cytomegalovirus (CMV), varicella-zoster virus (VZV), Epstein-Barr virus (EBV), human herpesvirus 6 (HHV-6), and the newly identified human herpesvirus 7 (HHV-7).

All human herpesviruses share some biological properties, such as their ability to cause latent infections and to infect epithelial cells and cells of the immune system. In contrast, major differences exist in their genome structure, specific features of their replicative cycle, their effects on host cells, and the clinical syndromes associated with their infection.

Herpesviruses are an important cause of morbidity and mortality in humans. Immunosuppressed patients are especially at risk of severe infections due to decreased immunosurveillance and loss of control of herpesvirus latency. Infections with herpesviruses are usually followed by latency, which is the capacity of the virus to remain in the cell with only partial expression of its genome.

This review will focus on infections due to HSV, VZV and EBV in organ transplant recipients.

\section{HERPES SIMPLEX VIRUS}

During primary infection with HSV-1 or HSV-2, the viral genome replicates in the skin or epithelium and virions then ascend by retrograde axonal transport in sensory nerve cells. HSV-1 causes the common cold sore and is the most common viral cause of blindness and sporadic encephalitis. It also causes aggressive infection in immunosuppressed patients.

In kidney allograft recipients, HSV infection occurs at rates as high as 70\% (2), but visceral dissemination is relatively rare. In the most recent review of herpes simplex infections in heart-lung transplant recipients (3), $45 \%$ of recipients were HSV antibody-positive at transplantation. Four of the 23 seropositive patients developed culture-proven superficial HSV lesions. In comparison, HSV pneumonia was diagnosed on six occasions in five patients. All occurred in patients who were HSV seropositive. Only one patient with HSV mucositis developed HSV pneumonia. One of the five patients died as a result of the HSV pneumonia despite therapy with intravenous acyclovir. A definite diagnosis of HSV pneumonia can be done only with a tissue biopsy; however, if biopsies are performed very early in infection it may not be possible to find characteristic inclusions by light microscopy. The results of tissue culture may give useful information and if they are positive for CMV and herpes simplex, immunohistochemical and DNA probe procedures may enhance specificity of diagnosis.

HSV infection may also involve other visceral organs such as the colon and liver, and these conditions usually have a fulminant course $(4,5)$. Acyclovir should be effective for treatment, but anecdotal reports suggest that invasive visceral disease occurs with strains that are acyclovir-resistant (6).

Herpes simplex diagnosis: Because infections with herpes simplex in immunosuppressed patients can have a fulminant course, it is important to collect specimens as early as possible in the course of the illness. Ideally cultures should be taken from cutaneous lesions that have reached the vesicle stage. The rate of viral isolation decreases as the lesions develop from vesicles to crusts. Swabs should be moistened with transport media, and for maximum isolation rate, specimens should be transported to the laboratory on the day of sampling. To maintain infectious virions, it is useful to inoculate cell culture at the bedside before and during transportation. There are several rapid techniques to demonstrate HSV infections, such as immunofluorescence of infected cells. Cells are collected with a large bore needle from the base of the vesicles, smeared onto glass slides and fixed in methanol. Virus-specific antigens are identified using monoclonal antibodies tagged with fluorescein. The vesicular fluid can also be analyzed by electron microscopy which will allow the detection of virions. Although serology can be useful in identifying patients who are at risk of acquiring reactivated infection, it is of very limited value during illness. Other techniques have been used for diagnosis confirmation, such as DNA amplification and in situ hybridi- 
zation to demonstrate visceral disease. Strains of HSV less sensitive to antiviral drugs have been observed in immunocompromised patients treated for long periods. Although this is not a widespread problem in the treatment or prophylaxis of HSV infections, it is increasingly seen in patients who have received long term therapy with antiviral agents.

\section{VARICELLA-ZOSTER VIRUS}

VZV is the cause of chickenpox and herpes zoster (shingles). In the immunocompromised host it may cause disseminated and occasionally fatal infections. The pathogenesis of VZV and chickenpox involves a primary asymptomatic infection of the oropharyngeal or conjunctival epithelium followed by viremia, viral replication in reticuloendothelial cells, and secondary viremia followed by infection of the skin and mucous membranes. Shingles is the counterpart of the common cold sore in varicella-zoster virus infections. The reactivation of a latent infection in sensory ganglia results in active replication of the virus, anterograde axonal transport, liberation of virions from the axons and, finally, dermatomal skin lesions.

VZV continues to be, with CMV, the most important cause of herpesvirus infections in immunocompromised patients. The probability of VZV infection is approximately $30 \%$ by one year after bone marrow transplantation. Most cases occur within the first nine months after transplantation. Peak occurrence of infection occurs during the fourth and fifth month after transplantation. Fifteen per cent of patients presenting with VZV infection develop varicella and 84\% develop zoster. Although the frequency of visceral dissemination and mortality is higher in patients with varicella than in patients with localized zoster, the incidences of subsequent visceral dissemination (36.6\%) and death $(18.3 \%)$ in patients with cutaneous dissemination of zoster are comparable to those in patients with varicella. The most significant risk factor for the development of disseminated VZV infection is acute and chronic graft-versus-host disease. Visceral disease involving the liver or lungs is manifest by elevated results of liver function tests and transient pulmonary infiltrates. Severe infections are more common in patients who develop an infection within nine months after transplantation than in those who have a later onset of the disease $(32 \%$ versus $19 \%, \mathrm{P}<0.05)$. The mortality rate of $\mathrm{VZV}$ infection in bone marrow transplant recipients is approximately $10 \%$. The mortality rate in patients with herpes zoster is around $6.6 \%$ and in patients with varicella it is approximately $28 \%$. Diffuse interstitial pneumonia develops in the majority of patients with fatal disease (87\%). Some patients with fatal infection do not develop skin lesions during the course of the illness. Among those patients with visceral dissemination, the mortality rate is $55 \%$ (7). The incidence of varicella-zoster in renal transplant recipients is around
$7 \%(8)$. Dissemination rates in solid organ transplants range from 25 to $50 \%$ (9). Postherpetic neuralgia is also an important sequela of zoster infection, cranial nerve herpes zoster may also cause corneal scarring, loss of vision and Bell's palsy with loss of hearing (RamsayHunt syndrome). A recent report suggests that VZV infections may present with clinical deterioration, fever and abnormal liver function tests and evidence of pancreatic involvement, two to five days before a skin eruption becomes apparent (10).

VZV diagnosis: VZV rapidly loses infectivity if not transported in suitable media. Swabs of lesions or vesicular fluid aspirates should be put immediately into viral transport medium and inoculated into tissue culture as soon as possible. It is recommended that sucrose phosphate $(0.2 \mathrm{M})$ should be used for transport to preserve the stability of VZV. As with herpes simplex infection, cells scraped from the base of skin lesions may be used for direct immunofluorescence staining for detection of VZV viral antigens. This technique can easily be used for confirmation of diagnosis. Electron microscopy examination of vesicle fluid is used for confirmation of the herpetic nature of skin lesions but cannot separate VZV from HSV infections. Methods for direct viral nucleic acid detection by dot hybridization or DNA amplification have also been developed and are quite sensitive and specific for confirmation of diagnosis. Antibody assays to demonstrate active VZV infection are of limited value in immunosuppressed patients. Most of these patients have reactivated infection. The demonstration of antibody to VZV by a wide variety of tests including complement fixation, fluorescent antibody membrane antigen and enzyme immunoassay is usually helpful in defining populations at risk among immunocompetent patients who are found to be seronegative. In immunocompromised patients, the presence of antibodies to VZV does not indicate a decreased risk for zoster or varicella.

Detection of VZV-specific antigens in biopsy material by immunofluorescence is rapid and reliable. For this purpose, monoclonal antibodies or antiserum specific for VZV is normally used.

\section{EPSTEIN-BARR VIRUS}

EBV causes heterophil antibody-positive acute infectious mononucleosis in young adults. The pathogenesis of acute infectious mononucleosis involves the replication of the virus in the oropharyngeal epithelium, followed by infection of $\mathrm{B}$ lymphocytes and an intense humoral and cellular immune response that results in the classical manifestations of infectious mononucleosis. These include lymphadenopathy, fever and sore throat. Active EBV replication, characterized by virus shedding in saliva, may be prolonged for weeks or months after infectious mononucleosis and during episodes of immunosuppression. EBV is also associated with lymphoproliferative disorders in organ transplant recipients and HIV-seropositive individuals. EBV may 
also have an etiological role in nasopharyngeal carcinoma and African Burkitt's lymphoma.

EBV in the oropharynx: Oropharyngeal epithelial cells provide the target for the replicative cycle of $\mathrm{EBV}$ in acute infectious mononucleosis and in the chronic carrier state $(11,12)$. EBV DNA and RNA can be demonstrated in oropharyngeal epithelial cells by in situ hybridization (13). Infectious virions can be detected by lymphocyte transformation in the saliva of individuals who acquire primary infections with EBV. Several studies have shown that 15 to $27 \%$ of EBV-seropositive individuals shed EBV in oropharyngeal secretions (1214). Other studies suggest that almost all EBV-seropositive individuals shed some virus, with the levels of excretion remaining constant in specific individuals over long periods of time (15). Whether the oropharynx is the source of infectious virions that cause infection and immortalization of B cells remains controversial, but after the administration of acyclovir, the oropharyngeal EBV shedding is inhibited, while the level of $B$ cells infected with EBV is unchanged (16).

EBV and B lymphocytes: EBV binding to B lymphocytes occurs by a specific interaction between the major viral envelope glycoprotein gp340 and the cellular receptor for the C3d component of complement (C3dR, also known as CD21 or DR2) (17). EBV-associated diseases, such as Burkitt's lymphoma, infectious mononucleosis and diffuse lymphoproliferative disorders, arise from infection of the B cell lineage. EBV induces normal B lymphocytes to proliferate in vitro and to become activated in long term cell lines that can be propagated in vitro indefinitely (18). The induction of indefinite B cell proliferation in vitro is termed 'transformation' or 'immortalization'. Although infection of lymphocytes by EBV is a necessary step in achieving B cell activation and immortalization (19), it has been shown that the transfer of EBV receptors to EBV receptor-negative cells, which allows the virus to infect cells and express some viral antigens, does not result in immortalization (20). After primary EBV infection of B cells in vivo, up-regulation of human interleukin-10, a potent B cell growth factor, is seen in vitro (21), which may explain the hyperproliferative response of B lymphocytes after infection.

Lymphoproliferative disorders occurring in organ transplant recipients have immunological features that in most cases identify them as polyclonal, and more rarely, as monoclonal in origin. The morphological characteristics exhibited by B cell lymphoproliferation in immunosuppressed patients include diffuse polymorphic B cell hyperplasia and diffuse polymorphic lymphoma (22). Most lymphoproliferative tumours contain EBV (23), and often occur in patients developing a primary EBV infection (24,25). Spontaneous regression often occurs in oligoclonal or polyclonal tumours after the dose of immunosuppressive medications is decreased (25), instead of the usual aggressive and fatal course seen in monoclonal lymphomas. Lymphoproliferative disorders in organ transplant recipients are the result of immortalization of B cells caused by EBV after primary infection, or the proliferation of latently infected cells unchecked by deficient T cell responses.

The analysis of the pattern of EBV gene expression with monoclonal antibodies in B cell tumours from eight organ transplant recipients demonstrated a latent/ nonproductive type of infection (27).

EBV diagnosis: Diagnosis of primary EBV infections in immunocompetent individuals is based on a typical clinical picture which usually includes a triad of symptoms including sore throat, fever and lymphadenopathy; there may also be a characteristic hematological picture with atypical lymphocytosis and a serological response. Confirmation of the diagnosis of infectious mononucleosis largely depends on the demonstration of heterophil antibodies in a patient's serum. These antibodies are detected just preceding or during the acute phase of infectious mononucleosis, and decrease to undetectable levels six months post infection (28). The production of heterophil immunoglobulin (Ig) $\mathrm{M}$ antibodies after EBV infection may be explained by the greater susceptibility to EBV infection of cell precursors committed to IgM production than of those committed to IgA or IgG production (29).

Antibodies to EBV-associated antigen: The detection of antibodies to specific EBV antigens is useful for identifying the small percentage of individuals who develop heterophil-negative infectious mononucleosislike disorders caused by EBV, and may also distinguish EBV-induced infectious mononucleosis from malignant diseases having features in common with primary EBV infection. The most useful test for the serological diagnosis of primary EBV infection is the IgM antibody to the viral capsid antigen (VCA). These antibodies appear early during the acute phase of infection, but disappear soon after the acute illness. VCA-IgG is used to determine whether a person has been infected with EBV. VCA-IgG antibodies appear soon after the onset of primary EBV infection, and it is difficult to demonstrate rising antibody titres unless the first serum is obtained very early during the acute phase of the illness. Because these antibodies persist at a high titre for a long period, they have only limited diagnostic value.

IgG antibodies specific for EBV early antigen are detected during acute or active EBV infection (30). Two types of early antigens have been described. The first is the 'diffuse' or 'D type' and is detected in both the nucleus and cytoplasm of infected cells. The second early antigen is termed 'restricted' or ' $\mathrm{R}$ type' and is detected only in the cytoplasm. Antibodies to the D type are detected in 70 to $80 \%$ of patients with acute EBV infection. These antibodies appear early during acute illness and decrease to undetectable levels during the convalescent phase of the illness. There are obvious limitations to the use of early antigen IgG (EA-IgG) 
antibodies in the diagnosis of active or reactivated EBV infections. Immunosuppressed patients and some nonimmunosuppressed individuals do not demonstrate EA-IgG antibodies during active EBV infection (24). Some asymptomatic individuals who do not have detectable EBV in throat washings demonstrate persistently high titres of EA-IgG antibodies (12).

EBV-induced nuclear antigens (EBNA) were initially demonstrated using the anticomplement immunofluorescence procedure. Antibodies against EBNA are detected weeks after the primary infection. There are six distinct EBV nuclear antigens (EBNA-1 to EBNA-6). Following infectious mononucleosis, antibodies to EBNA-2 are the first to appear, reaching peak titres after several weeks, and then declining to low or undetectable levels. Antibodies to EBNA-1 emerge several weeks or months after anti-EBNA-2 and gradually rise and persist indefinitely.

Detection of EBV infection by tissue culture: The 'gold standard' for identification of viruses in clinical specimens is tissue culture, whereby infectious EBV virions are detected by their ability to cause transformation of B lymphocytes. Infection of lymphocytes may then be confirmed by detection of EBNA using immunofluorescence. EBV is detected in oropharyngeal secretions of patients with primary infections, in EBVseropositive immunosuppressed patients and in some asymptomatic EBV-seropositive individuals. Ten to $60 \%$ of asymptomatic EBV-seropositive individuals and 90 to $100 \%$ of heterophil-positive infectious mononucleosis patients shed EBV in the oropharynx, as detected by the lymphocyte transformation assay. There are several factors which influence the detection of EBV by the lymphocyte transformation assay, including: EBV serostatus of the B cell donor; transforming activity of the EBV strain; history of the previous EBV infections; time since a primary EBV infection; integrity of the immune system; and in vitro conditions used in the assay. Several important factors should be considered when lymphocyte transformation is used to detect EBV. First, cord blood lymphocytes or lymphocytes from EBV-seronegative donors should be used for the assay because lymphocytes from EBV-seropositive individuals may contain EBV-infected cells or memory $\mathrm{T}$ cytotoxic cells specific for EBV-infected cells, which may inhibit the outgrowth of transformed lymphocytes. Second, transformation defective EBV strains may not be detected by this system. Sixbey et al (13) found that approximately half the individuals in whom EBV DNA was demonstrated in oropharyngeal secretions were negative for EBV by the lymphocyte transformation assay, and that most of the EBV DNA-positive, lymphocyte transformation-negative individuals were infected with an EBV variant that was transformation defective. There is some evidence that this transformation defective variant, or type 2 , virus is widespread in some parts of North America (13). Oropharyngeal shedding of EBV may persist at low levels in asymptomatic individuals for weeks or months after an initial episode of infectious mononucleosis. The present author has followed patients who excrete EBV for up to three years after infectious mononucleosis. Asymptomatic EBV-seropositive patients who are immunodeficient have a high rate of EBV excretion. The levels of oropharyngeal excretion of EBV may have a predictive value at the onset of illness in immunosuppressed individuals. Theoretically, lymphocyte transformation could detect as few as 30 virions, since one in 30 virions is infectious (31). Nevertheless, individuals excreting low or high levels of the virus will not be differentiated by lymphocyte transformation unless a limiting dilution assay of the transformed cells is used to quantify the level of virions excreted. This assay would not take into account the degree of transforming activity of different EBV strains. Another problem with the lymphocyte transformation assay is that it is time-consuming, taking three to six weeks to demonstrate virus in clinical specimens. Because of the limitations in the performance and interpretation of the lymphocyte transformation assay, DNA-based methods for the detection of EBV have been developed.

Detection of EBV infection by hybridization and by DNA amplification: Nucleic acid hybridization is a sensitive and specific method for demonstrating virusspecific DNA in clinical samples $(12,24)$. Unlike lymphocyte transformation assay, the nucleic acid hybridization system may detect noninfectious viral DNA and nontransforming variants with EBV. In addition, clinical specimens under long term storage for longitudinal studies may be analyzed for the presence of viral DNA (32). DNA amplification also allows for a detailed analysis of the genomic structure of EBV.

Early studies established that there is at least a $90 \%$ homology between EBV DNA of different origins (33). The areas of heterogeneity include the sequence of the EBNA-2 gene which has been useful in the typing of EBV isolates. Striking differences in the EBNA-2 encoded region have been found in isolates from Central Africa and strains isolated from North America. EBV isolates may be of two types according to the structure of the EBNA-2 gene or protein: type 1 or $\mathrm{A}$, and type 2 or B. EBNA-2A strains have been found in healthy EBV-seropositive individuals in the United Kingdom and Australia (34). In contrast, EBNA type 2B has been found in up to $40 \%$ of Burkitt's cell lines in the peripheral blood lymphocytes of $20 \%$ of adults in Africa $(34,35)$, and in $40 \%$ of patients with HIV infection (36). Amplification by polymerase chain reaction of the EBNA-2 gene can be used to characterize EBV isolates based on the high divergence of both the protein and DNA levels between the type 1 and type 2 variants. Type 2 transforms B cells less efficiently than type 1. In contrast to previous reports (25), Sixbey et al (13) found that infection by the type 2 variant is widely distributed 
in healthy EBV-seropositive individuals in North America. In their study of 34 individuals who excreted EBV DNA in throat washings, $41 \%$ were shedding type 2 virus, $50 \%$ were shedding type 1 and $9 \%$ were infected by both strains of the virus. In comparison, we found that of 34 organ transplant recipients who shed EBV DNA in the oropharynx, $79 \%$ shed EBV-1, $11.8 \%$ shed EBV-2, and $8.8 \%$ shed both EBV-1 and 2 (25), in contrast to our findings in lymphocytes of HIV-seropositive individuals in whom only type 2 strains were demonstrated, despite the prevalence of both types 1 and 2 , in oropharyngeal epithelial cells (37).

EBV infection in organ transplant recipients: Organ transplantation is a frequent form of treatment that requires immunosuppressive therapy and puts the patient at risk of developing opportunistic infections and de novo cancers. The risk of neoplastic disease is increased approximately 100-fold in organ transplant recipients, but it varies with the degree of immunosuppression, the immunosuppressive regimen employed, and the nature of the allograft. Except for skin cancers, the most common malignancies in this population are the lymphoreticular cancers associated with EBV. High titres of EBV-specific antibodies are frequently demonstrated in patients with immune deficiency (38). The high titres of EBV-specific antibodies probably reflect an increased activation of the virus in immunodeficient states. In contrast, many patients with severe EBV infections are immunodeficient and do not exhibit the typical clinical or immune responses that are present in normal individuals. For instance, some immunodeficient patients do not develop heterophil antibodies or EBV-specific IgM antibodies after primary infection $(27,38)$, and tests necessary for diagnosis, such as nucleic acid hybridization or lymphocyte transformation, are not generally available. In one study, 50\% of organ transplant recipients developing primary EBV infection did not have a specific IgM response to EBV VCA (25).

Individuals who undergo iatrogenic immunosuppression, such as organ transplant recipients, patients with congenitally acquired immunodeficiency and HIVseropositive individuals, are prone to developing active EBV infections and EBV-associated diseases such as hepatitis, encephalitis, bone marrow suppression, hemorrhage, pneumonitis, further immunosuppression resulting in opportunistic infections, and lymphoproliferative disorders (23). After renal transplantation, 1 to $13 \%$ of patients develop lymphoproliferative disorders (23).

We recently analyzed the quantitative oropharyngeal EBV shedding measured by a dot blot assay. The genotypes of isolates determined by DNA amplification were studied in 23 renal and 23 cardiac recipients over the first post-transplant year. In this population, five patients developed lymphoproliferative disorders and two additional patients with $\mathrm{B}$ cell tumour and renal transplantation were studied from the time of diagnosis. A significantly high level of EBV was found in primary versus reactivated infections. Higher levels of EBV were also found in patients who developed lymphoproliferative disorders than in patients who did not. Patients with the highest EBV shedding had the poorest serological responses, suggesting that patients with high viral antigen load had defective humoral responses to EBV. All patients who developed lymphoproliferative disorders and those without lymphoproliferation shed EBV type 1. In the same study, during the first posttransplant year, EBV excretion was detected at one or more sampling times in $82 \%$ of 23 renal and $95 \%$ of 23 cardiac and heart-lung transplant recipients by the dot blot assay. When both dot blot and DNA amplification were used, EBV was detected in 91\% of renal and $96 \%$ of cardiac and heart-lung transplant patients. Analysis of the quantitative oropharyngeal EBV shedding in this population demonstrated two subgroups of individuals: EBV-seropositive patients who excreted less than $100 \mathrm{pg}$ of EBV DNA per microgram of human DNA and were more likely to be intermittent shedders, and patients who demonstrated more than 1000 pg of EBV DNA per microgram of human DNA who were more likely to be persistent shedders.

The peak value of EBV shedding observed in individual patients in the first six months after transplantation was used to compare patients' groups. There was no significant statistical difference between renal and cardiac patients. Patients experiencing primary EBV infection had higher peak levels of EBV than patients seropositive before transplantation. Patients who received antithymocyte globulin or OKT3 antibody for induction or rejection therapy shed significantly higher peak levels of EBV than those who received neither therapy.

A fall in anti-EBNA IgG titre was observed in 15\% of seropositive patients. Two of the seven patients who developed lymphoproliferative disorder were EBV-seropositive before transplantation; these two patients did not have significant serological responses to EBV at diagnosis.

The incidence of lymphoproliferative disorders after solid organ transplantation varies from centre to centre, and depends largely on the serological EBV status before transplantation and on the immunosuppressive regimen used. At the University of Alberta Hospital, lymphoproliferative disorder has been diagnosed in 11 transplant recipients: four of 62 (2.5\%) receiving cadaveric kidneys, five of 69 heart recipients $(7.2 \%)$, and two of 10 heart-lung or lung transplant recipients $(20 \%)$. Patients who developed lymphoproliferation also developed significantly higher peak levels of EBV than those who did not. However, this reflects the high incidence of primary EBV infections in this population. Of seven patients who developed primary EBV infection after transplantation, five developed lymphoproliferative disorders. The two renal and cardiac transplant recipients who experienced primary EBV infection, but 
did not develop lymphoproliferation, had symptomatic primary and reactivated CMV infection at eight and seven weeks after transplantation, respectively. Both were treated with a reduction immunosuppression and the cardiac transplant recipient also received a twoweek course of ganciclovir therapy, which may explain the absence of lymphoproliferative disorders.

The role of the oropharyngeal epithelium in the outgrowth of transformed $\mathrm{B}$ cells resulting in $\mathrm{B}$ cell tumours in immunosuppressed patients remains unknown. Antiviral therapy at diagnosis has achieved only

\section{REFERENCES}

1. Roizman B, Batterson W. Herpesviruses and their replication. In: Fields, BN, ed. Fields' Virology. New York: Raven Press, 1985:497-520.

2. Pass RF, Long WK, Whitley RJ. Productive infection with cytomegalovirus and herpes simplex virus in renal transplant recipients: Role of source of kidney. J Infect Dis 1978; 137:556-62.

3. Smyth RL, Higenbottom TW, Scott JP, et al. Herpes simplex virus infection in heart-lung transplant recipients. Transplantation 1990;49:735-9.

4. Adler M, Golman M, Liesnart C. Diffuse herpes simplex virus colitis in a kidney transplant recipient successfully treated with acyclovir. Transplantation 1987;47:919-21.

5. Elliott WC, Houghton DC, Bryant RE, Wichlund R, Barry JM. Bennett WM. Herpes simplex type 1 hepatitis in renal transplantation. Arch Intern Med 1980;140:1656-1660.

6. Rogers TR. Infections complicating bone marrow transplantation. Curr Opin Infect Dis 1991;4:370-4.

7. Locksley RM, Flournoy N, Sullivan KM, Meyers JD. Infection with varicella-zoster virus after marrow transplantation. J Infect Dis 1985;152:1172-81.

8. Noel DR, Witherspoon RP, Storb R, et al. Does graft versus host disease influence the tempo of immunological recovery after allogenic human marrow transplantation? An observation on 56 longterm survivors. Blood 1978;51:1087-105.

9. Dolin R, Richman RC, Mazur MH, Whitley RJ. Herpes zoster varicella infections in immunosuppressed patients. Ann Intern Med 1878:89:375-88.

10. Schiller GJ, Nimer SD, Gajewski JL, Golde DW. Abdominal presentation of varicella-zoster infection in recipients of allogenic bone marrow transplantation. Bone Marrow Transplant 1991:7:489-91.

11. Sixbey JW, Vesterinen EH, Nedrud JG, Raab-Traub N, Walton LA, Pagana JS. Replication of Epstein-Barr virus in human epithelial cells infected in vitro. Nature 1983;306:480-3.

12. Diaz-Mitoma F, Preiksaitis JK, Leung W-C, Tyrrell DLJ. DNA-DNA dot hybridization to detect Epstein-Barr virus in throat washings. J Infect Dis 1987;155:297-303.

13. Sixbey JW, Shirley P, Chesney PJ, Buntin DM, Resnick L. Detection of a second widespread strain of Epstein-Barr virus. Lancet 1989;ii:761-5.

14. Gerber P, Nonoyama M, Lucas S, Perlin E, Goldstein LI. Oral excretion of Epstein-Barr virus by healthy subjects and patients with infectious mononucleosis. Lancet 1972;ii:988-9.

15. Yao QY, Rickenson AB, Gaston JSH, Epstein MA. A re-examination of the Epstein-Barr virus carrier state in healthy seropositive individuals. Int $\mathrm{J}$ Cancer 1985;35:35-42.

16. Yao 马Y, Ogan P, Rowe M, Wood M, Rickenson AB. Epstein-Barr virus-infected $B$ cells persist in the limited success. It is possible that prophylactic antiviral therapy initiated immediately after transplantation could prevent high peak EBV levels and perhaps decrease the level of EBV transformed B cells and the risk of developing lymphoproliferation. Patients who are EBV-seronegative before transplantation and receive an organ from an EBV-seropositive donor, or blood products from an EBV-seropositive donor, are at high risk of developing invasive B cell tumours, and, therefore, should be followed more closely for signs of lymphoproliferation.

circulation of acyclovir treated virus carriers. Int $\mathrm{J}$ Cancer 1989;43:67-71.

17. Nemerow GR, Mald C, Kievens-Schwerd V, Tallefson V, Cooper NR. Identification of gp350 as the viral glycoprotein mediating attachment of Epstein-Barr virus (EBV) to the EBV/C3d receptor of B cells. J Virol 1987;61:1416-20.

18. Pope JH, Horne MX, Scott W. Transformation of fetal leukocytes in vitro by filtrates of a human leukemic cell line containing herpes-like virus. Int J Cancer 1968;3:857-66.

19. Hutt-Fletcher LM, Fowler E, Lambris JD, et al. Studies of the Epstein-Barr virus receptor found on raji cells. II. A comparison of lymphocyte binding sites for Epstein-Barr virus and C3D. J Immunol 1983;130:1309-12.

20. Volsky DJ, Klein G, Volsky B, Shapiro IM. Production of infectious Epstein-Barr virus in mouse lymphocytes. Nature 1981;293:399-401.

21. Benjamin D, Knobloch TJ, Dayton MA. Human B-cell interleukin 10: B-cell lines derived from patients with acquired immunodeficiency syndrome and Burkitt's lymphoma constitutively secrete large quantities of interleukin-10. Blood 1992;80:1289-98.

22. List AF, Greco FA, Vogler LB. Lymphoproliferative diseases in immunocompromised hosts: The role of Epstein-Barr virus. J Clin Oncol 1987:5:1673-82.

23. Hanto DW, Frizzera G, Gagl-Peczalska KJ, Purtilo DT, Simmons RL. Lymphoproliferative diseases in renal allograft recipients. In: Portilo DT, ed. Immune Deficiency and Cancer. New York: Plenum, 1984:321-47.

24. Ho M, Miller G, Atchinson RW, et al. Epstein-Barr virus infections and DNA hybridization studies in posttransplantation lymphoma and lymphoproliferative lesions: Primary infection. J Infect Dis 1985; 152:876-86.

25. Preiksaitis JK, Diaz-Mitoma F, Mirzayans F, Roberts S, Tyrrell DLJ. Quantitative oropharyngeal Epstein-Barr virus shedding in renal and cardiac transplant recipients: Relationship to immunosuppressive therapy, serologic responses, and the risk of post-transplant lymphoproliferative disorders. J Infect Dis 1992;166:986-94.

26. Starzl TE, Nalesnik MA, Porter KA. Reversibility of lymphomas and lymphoproliferative lesions developing under cyclosporine-steroid therapy. Lancet 1984;i:583-7.

27. Thomas JA, Hotchin NA, Allday MJ, et al. Immunohistology of Epstein-Barr virus-associated antigens in B cell disorders from immunocompromised individuals. Transplantation 1990;49:944-53.

28. Evans AS, Niederman JC, Cenabre LC, West B, Richards VA. A prospective evaluation of heterophil and Epstein-Barr virus-specific IgM antibody tests in clinical and subclinical infectious mononucleosis: Specificity and sensitivity of the tests and persistence of antibody. $\mathrm{J}$ Infect Dis 1975; 132:546-54. 
29. Tosato G, Blaese RM. Epstein-Barr virus infection and immunoregulation in man. Adv Immunol 1985;37:99-153.

30. Henle G, Henle W. Immunofluorescence in cells derived from Burkitt's lymphoma. J Bacteriol 1966;91:1248-56.

31. Sugden B. Epstein-Barr virus: A human pathogeninducing lymphoproliferation in vivo and in vitro. Rev Infect Dis 1982;4:1048-61.

32. Diaz-Mitoma F, Ruiz A, Flowerdew G, Preiksaitis SK, Tyrrell DLJ. High levels of Epstein-Barr virus in the oropharynx: A predictor of disease progression in human immunodeficiency virus infection. J Med Virol 1990;31:69-75.

33. Kawai V, Nonoyama M, Pagano JS. Reassociation kinetics for Epstein-Barr virus DNA: Nonhomology to mammalian DNA and homology of viral DNA in various diseases. J Virol 1973; 12:1006-12.

34. Young LS, Yao QY, Rooney CM, et al. New type B isolate of Epstein-Barr virus from Burkitt's lymphoma and normal individuals in endemic areas. J Gen Virol
1987:68:2853-62.

35. Zimber V, Adldinger HK, Lenoir GM, et al. Geographic prevalence of two types of Epstein-Barr virus. Virology 1986; 154:56-66.

36. Sculley TB, Cross SM, Borrow P, Cooper DA. Prevalence of antibodies to Epstein-Barr virus nuclear antigen 2B in persons infected with the human immunodeficiency virus. J Infect Dis 1988;158:186-92.

37. Manion D, Conway B, Diaz-Mitoma F. Prevalence of lymphotropic variants in immunocompromised patients. Abstract 1717. 32nd Interscience conference on antimicrobial agents and chemotherapy. Anaheim, California, 1992.

38. Henle W, Henle G, Lennette ET. The Epstein-Barr virus. Sci Am 1979;241:48-59.

39. Frizzera G, Hanto DW, Gajl-Peczalska KJ, et al. Polymorphic diffuse B-cell hyperplasias and lymphomas in renal transplant recipients. Cancer Res 1981;41:4262-79. 


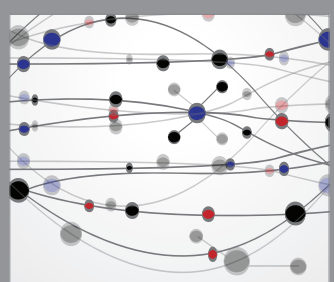

The Scientific World Journal
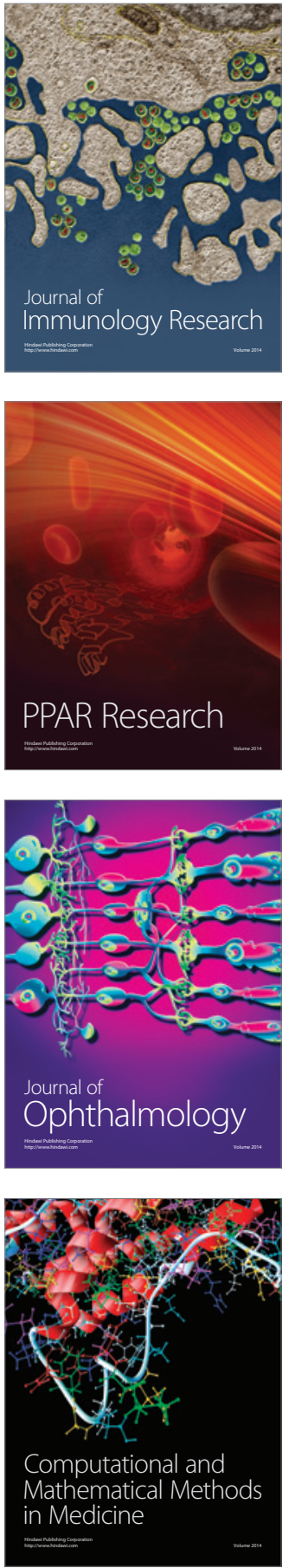

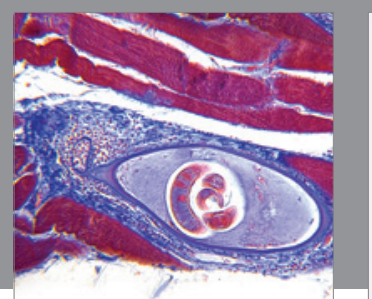

Gastroenterology Research and Practice

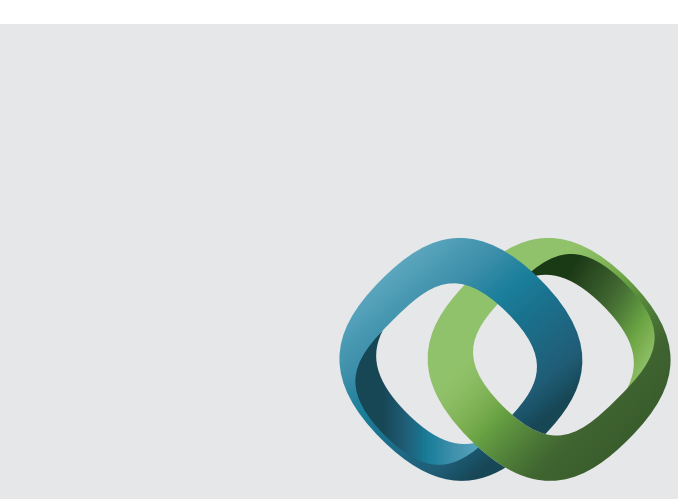

\section{Hindawi}

Submit your manuscripts at

http://www.hindawi.com
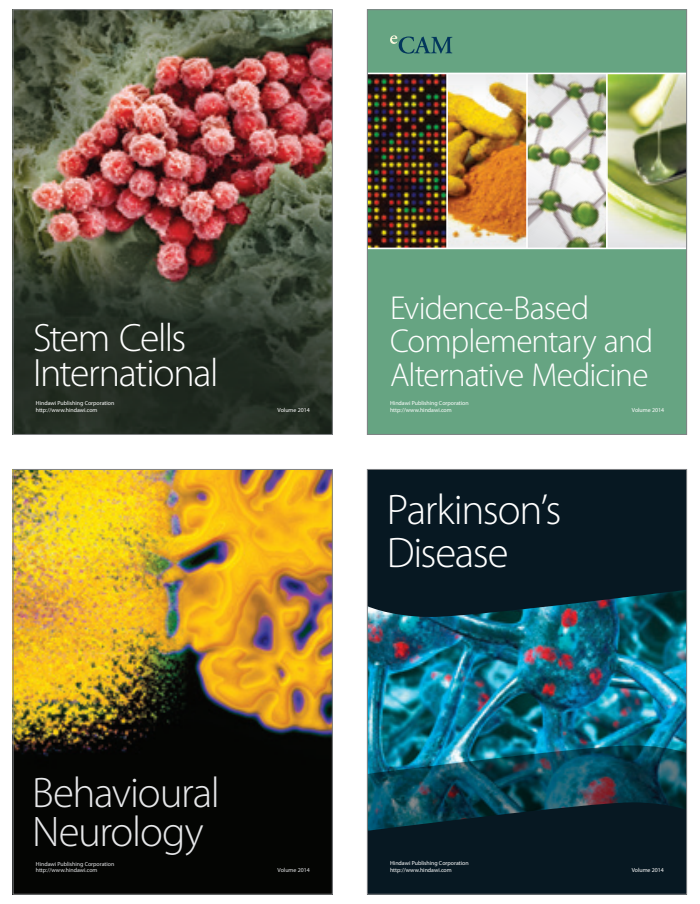
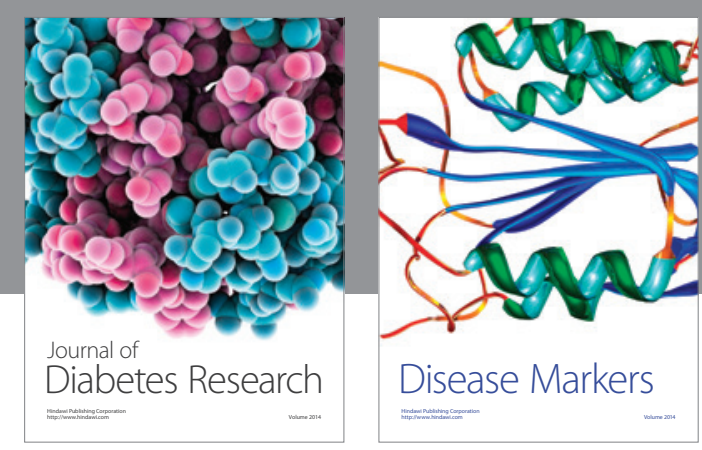

Disease Markers
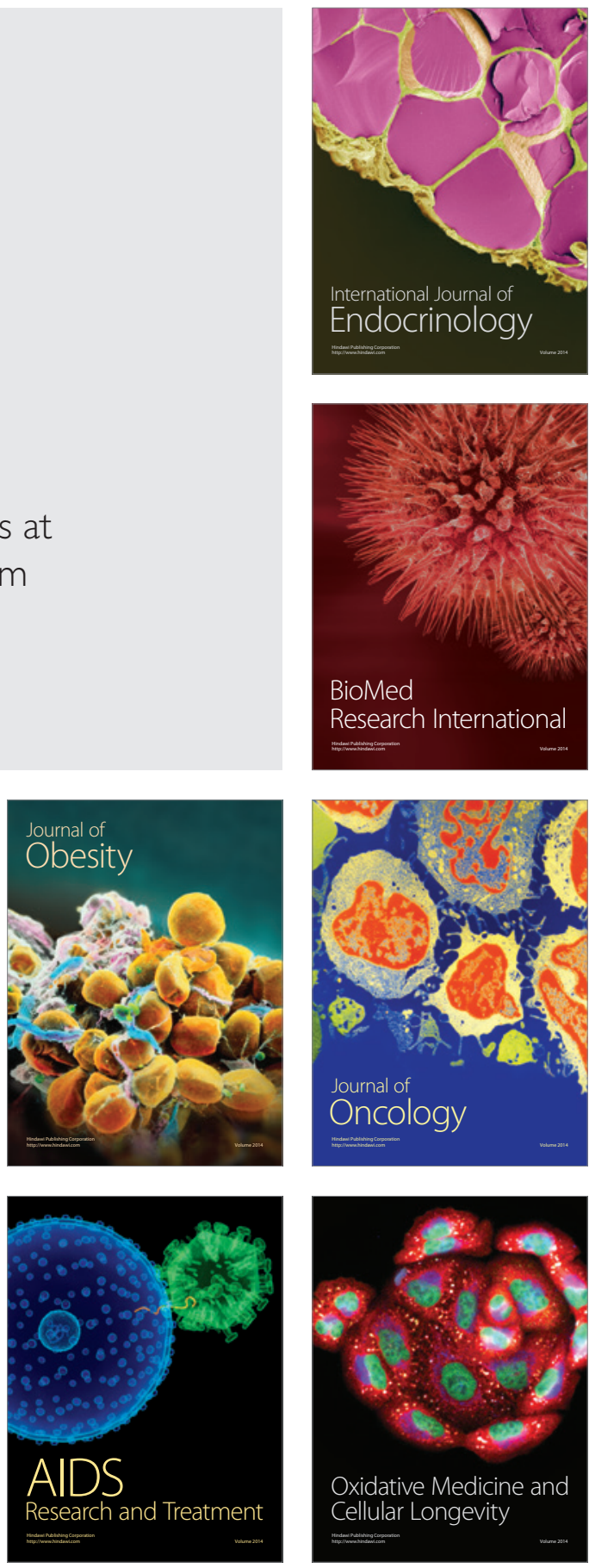